\title{
Internet Banking Adoption and Usage in Albania: An Empirical Study
}

\author{
Majlinda Godolja \\ University of Tirana, Albania \\ Email: majlinda.godolja@unitir.edu.al \\ Alma Spaho \\ University of Tirana, Albania \\ Email:alma.spaho@unitir.edu.al
}

Doi:10.5901/jesr.2014.v4n4p460

\begin{abstract}
The banking industry has undergone significant operational changes over the last decade, thanks to advances in information technology. The rapid diffusion of the Internet, in particular, has revolutionized the delivery channels used by the financial services industry. According to Central Bank of Albania, at the end of 2012, 11 banks in Albania provide internet banking services. Internet banking was the only home banking service during period 2005-2010. The number and value of internet banking transactions has increased from 2005 to 2012. The aim of this paper is to study the Internet banking usage by individual clients of banks in Albania. The objectives of this research are: to identify Internet banking services that banks' clients use and to identify the socio-demographic factors that influence the use of Internet banking. The target population was comprised by individuals that have a bank account. A questionnaire was distributed to banks' clients during November 2013. The hypothesis to be tested was: there exist any relationship between socio-demographic characteristics of the client (age, gender, residence, marital status, occupation, education level and monthly income level) and internet banking usage. To test the hypothesis chi-square test and logistic regression model was used. The results of statistical analysis indicated that banks' clients with high education level (university and master), and those with monthly income higher than ALL 90,000 were more likely to use Internet banking. The findings of this study provide useful information for planning Internet banking promotion strategies, focusing to clients with secondary education and with average monthly income.
\end{abstract}

Keywords: electronic banking services, socio-demographic characteristics, Chi-square test, logistic regression, Albania

\section{Introduction}

Interest in the adoption of Internet banking has recently increased due to the recognition of the crucial role of the Internet within the technological trajectory of Information and Communication Technologies (ICT) and to the growing importance of the information intensive service sectors such as the banking industry in the process of development and adoption of ICT-based innovations. The banking industry has undergone significant operational changes over the last decade, thanks to advances in information technology. The rapid diffusion of the Internet, in particular, has revolutionized the delivery channels used by the financial services industry.

Internet banking has advantages for banks to maintain competition, to save costs, to enhance mass customization, marketing and communication activities, and to maintain and attract consumers (Mols, 2000; Sheshunoff, 2000). According to Jayawardhena and Foley (2000), the main benefits to the banks are cost saving, reaching new segments of the population, efficiency, enhancement of bank's reputation and better customer service. Lee and Lee (2001) indicated that Internet banking allows consumers easier access to their bank accounts, lower service charges, and time saving. According to Laukkanen (2007), internet banking gives customers access to almost any type of banking transactions at the click of a mouse, except withdrawal 24 hours a day. The branch banking venue is characterised long winding queues and it is quite logical for the people with knowledge and accessibility to switch over to internet banking (Kerem, 2008). Moreover, Chang (2002) showed that Internet banking had a low transaction cost and a high speed of service when compared to other banking services. Internet banking has the advantage that the customer avoids travelling to and from a bank branch. In this way, Internet banking saves time and money, provides convenience and accessibility, and has a positive impact on customer satisfaction (Karjauloto et al., 2003). Customers can manage their banking affairs when they want, and they can enjoy more.

The first bank that offered the Internet banking was American Bank of Albania (now Intesa Sanpaolo Bank Albania) in 2002, with introduction of the first internet banking product ABAflex. At the end-2012, 11 banks in Albania (from 16 in total) provided internet banking services. Internet banking was the only home banking service during period 2005-2010, 
and during 2011- 2012 other services except phone banking were used. The number of transaction using internet banking has been increased from 15.706 in 2005 to 236.187 in 2012. The value of internet banking transactions (in ALL millions) has increased from 15.908 in 2005 to 117.233 in 2012. The number of customers' accounts accessible online at the end-2012 was around 55,000 and constituted $2 \%$ of the total number of customers account. In year 2008, the number of these accounts was 11,108 and constituted $0.7 \%$ of the total number of customer accounts (Bank of Albania, Annual Reports).

Individual characteristics such as age, gender, marital status, employment status, income level, and area of residence have been found to influence the behaviours of Internet banking customers (Sakkthivel, 2006; Lassar et al., 2005; Polasik and Wisniewski, 2009).

The objective of this research is to assess the impact of individual characteristics of the customers to the usage of Internet Banking in Albania using chi-square test and logistic regression model.

\section{Literature Review}

Individual characteristics such as age, gender, income, occupation and education play a vital role in understanding the buying behaviour of consumers in different segments, and when the characteristics are identified, they enable companies to develop products and services according to customers' specific requirements, tastes, and preferences (Sakkthivel, 2006). In addition, for Internet banking service adoption, banks must consider a user's demographic characteristics to offer the correct range of service products. Several studies have been conducted to profile the Internet consumer's demographic characteristics and the results of these studies suggest that innovators who belong to the high income category are normally initial users of the Internet (Flynn and Goldsmith, 1993; Gan et al., 2006). Further, Sakkthivel (2006) reveal that the profile of an Internet user tends to be young, male, well educated, and earning an above-average income. According to Polatoglu and Ekin (2001) and Howcroft et al., (2002), characteristics that describe typical electronic banking customers include young, affluent, and highly educated. A Finnish study of Mattila (2003) reveals Internet banking users are relative wealthy, highly educated, and are in higher professions. Awamleh and Fernandes (2006) also find that in United Arab Emirates, young affluent and highly educated groups generally accept technological changes more readily. Sathye (1999) indicated that young, educated, and wealthy consumers were among those most likely to adapt online banking in Australia.

A typical internet banking user is usually identified as to be younger, better educated, wealthier and with a good knowledge of computers and especially the internet (Al- Somali et al 2009; Lea et al. 2003; Karjaluoto et al., 2002). In their study Lee and Lee's (2001) showed that adopters of Internet banking tend to be more highly educated, more wealthy and younger with good knowledge of computers and especially familiarity with internet usage.

\section{Research Methodology}

The population of the study consisted of Albanian individuals who have a bank account and use banking services. Data collection was conducted based on a self-administered questionnaire. In total, 250 questionnaires were distributed to individuals who use banking service during November 2013. Only 122 questionnaires were returned and were useful for the data analysis, representing a $48.8 \%$ response rate. The questionnaire included questions about: respondents' profile; period of time using computer and internet; computer literacy and internet literacy; and the internet banking services used.

To analyze the relationships between individual charecteristics and the usage of internet banking firstly was used the chi-square test of independence and then, to assess the simultaneous influence of all demographic variables on the usage of internet banking, binary logistic regression was used.

The chi-square test of independence is used to test the independence of the two categorical variables (that is, there is no relationship between them). The test statistics is:

$$
\chi^{2}=\sum_{i=1}^{n} \sum_{j=1}^{m} \frac{\left(f_{i j}-p_{i j}\right)^{2}}{p_{i j}}
$$

where: $n$ indicates the number of columns and $m$ the number of rows of the contingency table; $f_{i j}$ are observed frequencies in the ij cell of the $n \times m$ contingency table, whereas $p_{i j}$ are expected frequencies in the ij cell if the null hypothesis of independence was true. The test statistics approximately follows a chi-square distribution with degree of freedom equal to $(n-1)(m-1)$. The null hypothesis of independence of two variables is rejected at the level of significance $a$, if $p$-value $<a$.

A logistic regression model with a dichotomous response of use or not use was modelled. For the analysis, the 
response was coded as 1 or 0 , respectively. Logistic regression is recommended over linear regression when modelling dichotomous responses and allows the researcher to estimate probabilities of the response occurring (Hosmer and Lemeshow, 2004). The logistic regression equation takes the following form

$$
\ln \left(\frac{p}{1-p}\right)=\beta_{0}+\beta_{1} x_{1}+\beta_{2} x_{2}+\ldots+\beta_{k} x_{k}
$$

$p$ is the estimated probability that the customer to use the internet banking, and $x_{1}, x_{2}, \ldots, x_{k}$ are independent variables of the model.

The estimated probability of the response occurring ( $p)$ divided by the probability of it not occurring (1-p) is called the odds ratio. Maximum likelihood method is used to estimate the odds ratios of the model. Values of odds ratios higher than 1 indicate positive association between the variables, odds ratios equal to 1 indicate no association, while odds ratios lower than 1 indicate negative association between each independent variable and the dependent variable of the model.

STATA12 was used to conduct the descriptive analysis and to test the formulated hypothesis using Chi-square test and logistic regression model.

\section{Results and Discussion}

The respondents were from Tirana (67\%), Durres (13\%), Korca (10\%) and Vlora (10\%). Out of the 122 respondents, around $83 \%$ of them live in urban area, $51 \%$ were male, $50 \%$ were married and $49 \%$ were between 18 and 28 years old. Most of the respondents (29.5\%) have completed university, and $26.2 \%$ have completed master's degree. Majority of the respondents (54\%) were professional employees (mainly economists, teachers/professors, engineers, doctors), 22\% were simple workers and $13 \%$ students. Around $47 \%$ of the respondents had monthly income between ALL 30000 and ALL 60 000. The majority of the respondents for at least 6 years have been using computer (56.5\%), internet (44.3\%), and banking services (41.8\%). With regards to computer literacy, around $42 \%$ of the respondents declared that they had advanced level of computer use, and $41 \%$ intermediate level of computer use. With regards to Internet literacy, about $44.3 \%$ of the respondent declared that had advanced level of internet use, and $37.7 \%$ intermediate level of internet use.

The internet banking channel was used by $27 \%$ of the respondents. The internet banking services used by majority of the respondents were: account(s) balance and its transactions (around 68\%) and credit/debit card statements (around $65 \%)$.

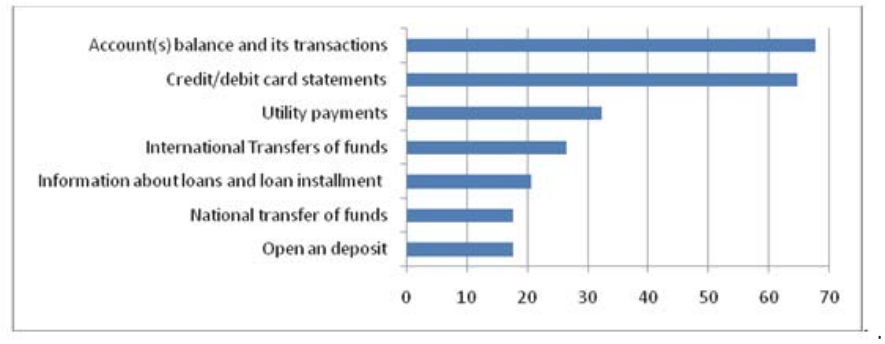

Figure 1. The internet banking services used by respondents $(n=34)$

\subsection{Association between Internet banking usage and individual characteristics of users}

The results of bivariate analysis, chi-square test of independence, indicated the association of individual characteristics of the respondents with the use of internet banking. 
Table 1. Chi-square tests results

\begin{tabular}{lcc}
\hline \multicolumn{1}{c}{ Characteristic } & Chi-square (df) & p-value \\
\hline Age & $5.99(2)$ & 0.050 \\
Gender & $0.27(1)$ & 0.606 \\
Residence & $2.33(1)$ & 0.127 \\
Marital status & $0.06(1)$ & 0.806 \\
Education level & $33.05(2)$ & 0.000 \\
Monthly income level & $26.54(2)$ & 0.000 \\
\hline
\end{tabular}

The results of table 1 indicated that age, education level and monthly income level were significantly related to internet banking usage at $5 \%$ level, whilst gender, residence and marital status were not related to Internet banking usage at 5\% level. Young respondents, those with high educated level and with high income level were more likely to use Internet banking compared to others. These findings are consistent with the finding of Sakkthivel's (2006), Howcroft et al., (2002) and Sathye (1999).

The result of chi-square test indicated significant relationship between computer literacy (chi2(3) $=22.9, p<0.01$ ) and Internet banking usage, and between Internet literacy and Internet banking usage (chi2(3) $=25.3, p<0.01$ ). These findings were consistent with the findings of Lee and Lee (2001).

\subsection{The results of logistic regression model}

The correlation coefficients between independent variables of the model were assessed to check for the problem of multicollinearity. Marital status of the respondent was highly correlated with age $(r=0.72, p<0.01)$.

Tabela 2. Correlations matrix

\begin{tabular}{lcccccc}
\hline & Age & Gender & Residence & Marital Status & Education level & Monthly Income level \\
\hline Age & 1.000 & & & & & \\
Gender & $0.191^{*}$ & 1.000 & & & & \\
Residence & -0.152 & -0.057 & 1.000 & & & \\
Marital status & $0.721^{*}$ & 0.048 & 0.016 & 1.000 & 1.000 & 1.000 \\
Education level & -0.064 & $-0.198^{*}$ & 0.119 & 0.036 & $0.543^{*}$ & \\
Monthly Income level & 0.109 & 0.116 & 0.154 & 0.116 & & \\
\hline
\end{tabular}

Note: ${ }^{*} p<0.05$.

The results of logistic regression model indicated that the model was statistically significant $(\operatorname{LR} \operatorname{chi} 2(7)=42.72, p<$ 0.05). Pseudo- $R^{2}$ value was $29.6 \%$ and the percentage of correctly classified cases was $78.7 \%$. According to Hair et al. (2009), the classification accuracy should be at least $25 \%$ greater than that achieved by chance.

Table 3. Logistic regression results

\begin{tabular}{lcc}
\hline \multicolumn{1}{c}{ Variabli } & Frequency & Odds ratio \\
\hline Age & & \\
$18-28$ & 49.2 & 1.00 \\
$29-39$ & 24.6 & 0.87 \\
$40+$ & 26.2 & 0.42 \\
Gender & & \\
Male & 50.8 & 0.92 \\
Female & 49.2 & 1.00 \\
Residence & & \\
Urban & 82.8 & 1.19 \\
Rural & 17.2 & 1.00 \\
Education level & & \\
8-9 years/secondary & 35.2 & 1.00 \\
University/Master + & 64.8 & $17.4^{*}$ \\
Monthly income level (ALL) & 70.5 & 1.00 \\
Less than 60,000 & 29.5 & $5.38^{*}$ \\
More than or 60,00 & & \\
\hline p $0.05,{ }^{* *} p<0.10$ & &
\end{tabular}


The results of table 3 indicated that education level and monthly income were statistically significant, whereas age, gender and residence were not significant at $5 \%$ level. The variable education level was significant at $5 \%$ level; this means that clients with high education level were more likely to use internet banking. The other significant variable at $5 \%$ level, monthly income level, indicated that clients with monthly income higher than ALL 60,000 were more likely to use Internet banking. This result is consistent with the finding of Sathye (1999) and Lee and Lee (2001).

\section{Conclusions}

This study examined the impact of individual characteristics on the use of Internet banking in Albania. The results of the statistical analysis showed that there is an association between usage of Internet banking and characteristics of users. The results of chi-square tests indicated that internet banking users were more educated and with high income level, also the young customers with age 18-29 were more familiar with internet banking. The results of logistic regression analysis indicated that customers with university or master education and those with monthly income over ALL 60.000 were more likely to use internet banking. Also, young, male and urban customers tent to use more internet banking than others.

The findings of this study provide useful insights into the Internet Banking market in Albania. Specifically, the findings indicated that for purposes of marketing their Internet banking services, financial institutions must consider differentiation based on characteristics of the users. Role of bank should increase related to awareness and education of their clients regarding to all their internet banking services, as well as security and privacy of their account, and also banks should give their clients more information about benefits of internet banking.

This study has some limitation. First, the study is limited to consumers in several urban and rural areas. Second, the sample size is relatively small. Third, the study is limited to the investigation of the associations between individual characteristics of the customer and the usage of Internet Banking. Other variables can be examined such as, convenience, trust, security, fees and charges, etc.

The above limitations provide opportunity for future research. In particular, there is need for a nationwide study of Internet Banking usage behaviour in Albania. In the future research, it would be useful to take into consideration the frequency of Internet banking use and the value of transactions for each customer, which would provide a better understanding of factors that influence its use.

\section{References}

Al- Somali, S. A., Gholami, R., and Clegg, B., (2009), "An investigation to online banking in Saudi Arabia" Technovation, vol 29, 130-141 Awamleh, R., and Fernandez, C. (2006), Diffusion of Internet banking amongst educated consumers in a high income non-OCED country. Journal of Internet Banking and Commerce, 11 (3).

Bank of Albania, Annual Reports 2012, www.bankofalbania.org

Chang, Y. (2002). Dynamics of banking technology adoption: An application to Internet banking. Working Paper. University of Warwick.

Flynn, L. R., and Goldsmith, R. E. (1993), Application of the Personal Involvement Inventory in Marketing, Psychology and Marketing, 10 (4), pp.357-336.

Gan, C., Clemens, M., Limsombunchai, V., and Weng, A. (2006), A Logit Analysis Of Electronic Banking in New Zealand. International Journal of Bank Marketing, 24 (6) pp. 360-383.

Hair, J.F., Black, W., Babin, B.J., Anderson, R.E. (2009). Multivariate Data Analysis. $7^{\text {th }}$ ed.

Hosmer, D.W., Lemeshow, S. (2004). Applied Logistic Regression, 2nd ed.

Howcroft, B., and Hamilton, R., and Hewer, P. (2002), Consumer attitude and the usage and adoption of home-banking in the United Kingdom. International Journal of Bank Marketing. 20 (3), 111-121.

Jayawardhena, C. and Foley, P. (2000), Changes in the banking sector - the case of Internet banking in the UK. Internet Research. 10(1), pp.19-30.

Karjaluoto, H., Koivumaki, T., and Salo, J. (2003), Individual differences in private banking: empirical evidence from Finland. Proceedings of the 36thHawaii International Conference on System Sciences (HICSS), Big Island, Hawaii.

Karjaluoto, H., Mattila, M., Pento, T., 2002. Factors underlying attitude formation towards online banking in Finland. International Journal of Bank Marketing 20 (6), 261-272.

Kerem, K. (2008), Adoption of Internet banking. I4d magazine (India), April 2008, pp 10-12.

Lassar, W.M., Manolis, C., Lassar, S.S. (2005) The relationship between consumer innovativeness, personal characteristics, and online Banking adoption . International Journal of Bank Marketing 23 (2): 176 - 199.

Laukkanen, P., Sinkkonen, S., Kivijärvi, M., and Laukkanen, T. (2007). Consumer Resistance and Intention to use Internet banking service. Proceedings of the EBRF Conference, Jyväskylä, Finland, September 25-27, 2007.

Lea, E., Lee, J. and Eastwood, D. (2003), "A two-step estimation of consumer adoption of technology based service innovations", The Journal of Consumer Affairs, Vol.37, No.2, pp. 256-82.

Lee, E., and Lee, J., (2001). "Consumer Adoption of Internet Banking: Need-Based and/or Skill Based", Marketing Management Journal 
11 (1), pp. 101-113.

Mattila, M. (2003), Factors affecting the adoption of mobile banking services. Journal of Internet Banking and Commerce, 8(1).

Mols, N. P. (2000). The Internet and services marketing: The case of Danish retail banking. InternetResearch: Electronic Networking Applications and Policy, 10(1), 7-18.

Polasik, M . and Wisniewski , T . P . ( 2009 ) Empirical analysis of Internet Banking in Poland . International Journal of Bank Marketing 27 (1) : $35-52$.

Polatoglu, V. N. and Ekin, S. (2001). An empirical investigation of the Turkish consumers' acceptance of Internet banking services. International Journal of Banking Marketing, 19(4),pp.156-165.

Sakkthivel, A. M. (2006), Impact of Demographics On The Consumption Of Different Services Online India. Journal of Internet Banking and Commerce. 11 (3).

Sathye, M. (1999). Adoption of Internet banking by Australian consumers: an empirical investigation. International Journal of Bank Marketing, Vol. 17 No. 7, pp. 324-34.

Sheshunoff, A. (2000). Internet banking: An update from the frontlines. ABA Banking Journal, American Bankers Association, 92(1), 5153. 